\title{
Clinical Applications of Wideband Tympanometry
}

\author{
Moo Kyun Park \\ Department of Otorhinolaryngology-Head and Neck Surgery, Seoul National University College of Medicine, Seoul, Korea
}

\section{Wideband Tympanometry의 임상적 활용}

\author{
박 무 균 \\ 서울대학교 의과대학 이비인후과학교실
}

\author{
Received June 23, 2017 \\ Revised July 11, 2017 \\ Accepted July 12, 2017 \\ Address for correspondence \\ Moo Kyun Park, MD, PhD \\ Department of Otorhinolaryngology- \\ Head and Neck Surgery, \\ Seoul National University \\ College of Medicine, 101 Daehak-ro, \\ Jongno-gu, Seoul 03080, Korea \\ Tel +82-2-2072-2446 \\ Fax $+82-2-745-2387$ \\ E-mail aseptic@snu.ac.kr
}

Conventional impedance audiometry uses only specific tympanometric frequencies (e.g., 226 $\mathrm{Hz}$ ) and cannot test above $1500 \mathrm{~Hz}$. As many hearing frequencies must be evaluated when diagnosing middle ear pathologies, wideband clicks stimulating tympanometric receptors from 226 to $8000 \mathrm{~Hz}$ are commonly delivered. Since wideband tympanometry (WBT) was introduced in 1993, several studies have explored its clinical utility. WBT yields information on absorbances at various frequencies and pressures. Recently, WBT has become increasingly used to diagnose and monitor the hearing of newborns and patients with otosclerosis, ossicular chain disruptions, tympanic perforations, superior semicanal dehiscence syndrome, and middle ear effusions. WBT is also employed for pre/postoperative monitoring using non-pressurized wideband absorbance. Here, we review the concept of WBT, the basic mechanism, and the clinical applications. Korean J Otorhinolaryngol-Head Neck Surg 2017;60(8):375-80

\section{Introduction}

We commonly employ tympanometry at $226 \mathrm{~Hz}$ but sometimes at $220 \mathrm{~Hz}$, associated with microphone constraints, not diagnostic utility. Calibration at only $226 \mathrm{~Hz}$ was available when tympanometry was first introduced. The ear canal behaves as a hard-walled cavity at $226 \mathrm{~Hz}$, and the compliance: admittance ratio is $1: 1$ at this frequency. ${ }^{1,2)}$

Tympanometry at $226 \mathrm{~Hz}$ has been used to detect middle ear effusions, and is optimally $80 \%$ sensitive and $70 \%$ specific. ${ }^{3)}$ A flat type 'B' tympanogram by Jergers classification exhibits high specificity but only $10 \%$ sensitivity. In addition, $226-\mathrm{Hz}$ data poorly predict middle ear effusions in infants, yielding erroneous data in approximately $50 \%$ of cases. ${ }^{4)}$ Tympanometry at $1000 \mathrm{~Hz}$ is better, but the data are erroneous in

This is an Open Access article distributed under the terms of the Creative Commons Attribution Non-Commercial License (http://creativecommons.org/licenses/by-nc/4.0) which permits unrestricted non-commercial use, distribution, and reproduction in any medium, provided the original work is properly cited. about $10 \%$ of cases. ${ }^{5,6)}$ Conventional $226-\mathrm{Hz}$ tympanometry is of low diagnostic utility in the diagnosis of otosclerosis. Type 'A' tympanograms are observed in $95 \%$ of cases. ${ }^{7,8)}$ Conventional tympanometry is also of low diagnostic utility when employed to evaluate other diseases. For example, tympanometry at $220 \mathrm{~Hz}$ detects only $42 \%$ of patients with ossicular discontinuities when type 'A' tympanograms are evaluated. ${ }^{9)}$

As a wide frequency range is required to detect middle ear pathologies and to distinguish them from one another, several studies have sought to apply wide-range stimulation. Keefe, et al. ${ }^{10)}$ and Voss and Allen ${ }^{11)}$ were the first to develop the wideband, power-based, response function parameters of acoustic impedance, admittance, and reflectance in the human ear. Wideband tympanometry (WBT) yields additional valuable data. The ability to derive wideband acoustic estimates of middle ear function under ambient ear canal conditions is especially significant in newborns and infants. ${ }^{6,12)}$

Conventional tympanometry uses a single frequency, 226 
$\mathrm{Hz}$, to detect problems in the tympanic membrane and ear cavity. WBT employs wideband click stimuli to assess middle ear pathologies at multiple frequencies and detects problems with high accuracy. ${ }^{8,13,14)}$ Conventional tympanometry measures ad- mittance and compliance, but cannot explore frequencies $>1500$ $\mathrm{Hz}$ because of issues with standing waves. WBT can test up to $8000 \mathrm{~Hz}$, evaluating absorbance rather than admittance. The absorbance contains the same information as admittance,
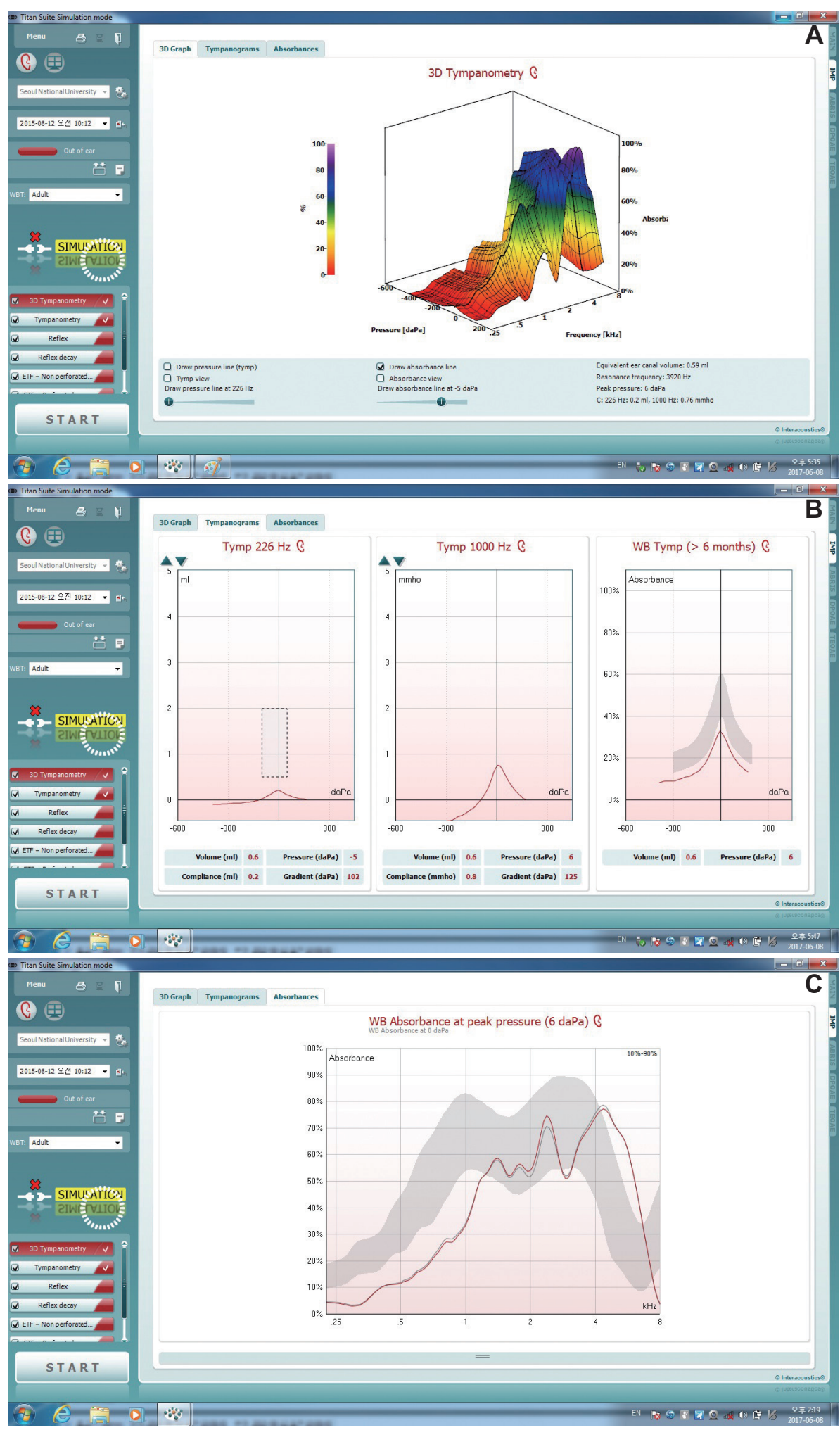

Fig. 1. A typical WBT dataset composed of a three-dimensional graph, a three-dimensional tympanogram, and absorbance data. The three-dimensional tympanogram shows all resonance frequencies by pressure (A) and all data yielded by conventional tympanography at 226 or 1000 $\mathrm{Hz}$ in addition to a wideband averaged tympanogram (B). The $\mathrm{x}$-axis shows the frequency in $\mathrm{kHz}$ and the $y$-axis absorbance. The test can be performed at peak tympanic pressure or ambient pressure. The gray graph shows normative absorbance data. This test was run at peak pressure (6 daPa) (C). 
but that the absorbance graph provides additional information that can be used in the differential diagnosis for middle ear pathologies (Fig. 1). ${ }^{15)}$ Absorbance is: absorbed sound/incident sound, or 1 minus the energy reflectance. Absorbance can be measured during WBT or at ambient pressure.

\section{Clinical Applications}

\section{Normative studies}

Clinicians must consider normative data before interpreting the absorbance graph. Age, gender, ear, body size, and race can affect WBT values, attributable to differences in ear canal mobility, and the size and length of the outer and middle ear structures. ${ }^{16-19)}$ The use of data derived from studies differing in age, race, and sex improves diagnostic utility. The use of ageand ethnicity-specific norms are recommended when diagnosing otosclerosis. ${ }^{17)}$ Australian Aboriginal and Caucasian neonates require a broader set of normative data. Aboriginal neonates exhibit significantly lower absorbances than Caucasians, but equivalent pass rates. ${ }^{18)}$ WBT exhibits a multi-peak pattern in infants aged $0-2$ months, but a single broadly peaked pattern in those aged 4-6 months. ${ }^{20)}$ Özgür, et al. ${ }^{21)}$ developed normative data for Turkish populations. The resonance frequency was low in those aged $0-1$ months and the absorbance at $250 \mathrm{~Hz}$ was high in those aged 0-2 years. Aithal, et al. ${ }^{22)}$ derived normative WBT data for Caucasian neonates. WBT at $1-4 \mathrm{kHz}$ was optimal when evaluating the outer and middle ear. Frequencies above $4 \mathrm{kHz}$ yielded variable data. Polat, et al. ${ }^{23)}$ found that the use of different norms for males and females increased the diagnostic specificity and sensitivity of ossicular discontinuities and tympanic membrane perforations affecting high-frequency hearing. The side of the ear may also affect the results. Left ears exhibited greater energy reflectance at 1.0 and $2.0 \mathrm{kHz}{ }^{24)}$ In addition, WBT performed at ambient or peak pressure affect the normative data and may be clinically valuable in patients with either negative or positive middle ear pressure. The differences between systems are not clinically significant. ${ }^{17)}$ Sun ${ }^{25)}$ reported normative adult WBT data; the test-retest reliability was excellent. Keefe, et al. ${ }^{26)}$ evaluated down- and up-swept tympanograms using acoustic stimulation of the ear canal to calculate reflectance. Ryu and $\mathrm{Cho}^{27)}$ derived normative data for Koreans. The WBT absorbances of those aged 17-29 years were higher at $1.6-3.2 \mathrm{kHz}$. Males exhibited higher absorbances at low frequencies and females at high frequencies, especially $4 \mathrm{kHz}$. The use of such data increased diagnostic precision.

\section{Improvements in tympanometry}

WBT improves tympanometry by yielding tympanograms of various frequencies, including resonance frequency tympanograms that determine whether the ear problem is massor stiffness-predominant. Some clinicians use such data to detect otosclerosis and ossicular chain abnormalities. ${ }^{8,28)}$ The average adult value is $375-2000 \mathrm{~Hz}$, but $800-2000 \mathrm{~Hz}$ in infants; such frequency data are used to detect middle ear effusions. They are minimally noise-sensitive, yielding clean traces from even noisy patients such as on infants. A comparison between WBT at $1250 \mathrm{~Hz}$ and static admittance at $226 \mathrm{~Hz}$ found that WBT best distinguished between healthy ears and those with a middle ear effusion. ${ }^{29)}$ High-frequency tympanometry yields better results in younger infants, and low-frequency tympanometry better results in older infants. However, the optimal frequencies detecting middle ear problems in infants aged 4-8 months remain unclear. WBT yields tympanograms at both 226 and $1000 \mathrm{~Hz}$, allowing clinicians to compare low- and high-frequency data. Terzi, et al. ${ }^{13)}$ found that the wideband acoustic absorbance rate (the $0.375-2-\mathrm{kHz}$ average mean absorbance) was significantly lower in patients suffering from otitis media with effusion than in those with simple otitis media, or healthy subjects $(p<0.017$ and 0.001 , respectively).

\section{New Contributions to Differential Diagnoses}

\section{Otosclerosis}

Otosclerotic 226-Hz tympanograms are often very similar to normal tympanograms. Static immittance recorded at higher probe-tone frequencies is superior to that measured using standard low probe-tones in the diagnosis of otosclerotic ears. ${ }^{8)}$ Furthermore, it is not easy to monitor disease progression using only audiometric and acoustic reflex data. WBT absorbance and resonance data can be used to detect and monitor otosclerosis. The absorbance at peak pressure differs from that of normal ears. Otosclerosis is associated with low absorbance at $<1 \mathrm{kHz}^{28,30)}$ In addition, changes in resonance frequency over time may indicate disease progression. Although the resonance frequencies differ significantly among individuals, the frequency should be stable in ears with normal middle ear function. As otosclerosis progresses, the middle ear stiffens, causing the resonance frequency to increase over time. ${ }^{8,28,30)}$ 


\section{Middle ear problems in infants}

Tympanometry using higher probe-tone frequencies yields more sensitive data than does conventional low probe-tone tympanometry when middle ear disease is suspected in newborn infants. ${ }^{12)}$ WBT adds high-frequency information. In addition, WBT yields a wideband-averaged tympanogram. In infants, tympanograms from 800 to $2000 \mathrm{~Hz}$ are averaged to yield a single curve. For patients older than 6 months, the appropriate range is 375 to $2000 \mathrm{~Hz}$. An averaged curve is less sensitive to noise than are tympanograms recorded at single frequencies; averaging reduces noise. In addition, WBT can differenciate between an airfilled ear and an ear with complete otitis media with effusion (OME) using the absorbance graph. ${ }^{29,30)}$

Guan, et al. ${ }^{31)}$ described the factors affecting sound energy absorbance in a chinchilla model of acute otitis media. Middle ear pressure was the principal contributor to a reduction in sound energy absorbance in early-stage disease. Middle ear effusion reduced the sound energy absorbance at $6-8 \mathrm{kHz}$ in early-stage disease and at $2-8 \mathrm{kHz}$ on day 8 of disease. A loss of residual sound energy absorbance attributable to structural changes was evident over the entire frequency range on day 8 of disease, but only at high frequencies in early-stage disease. Aithal, et al. ${ }^{14)}$ reported that the $1-4-\mathrm{kHz}$ region could be optimally used to evaluate the conductive status of newborns.

\section{Newborn hearing screening (NHS)}

WBT can be used for newborn hearing screening (NHS). WBT and wideband reflexes could be more accurate than 256 or $1000 \mathrm{~Hz}$ tympanometry. Power reflectance measurements are significantly different for ears that pass NHS and ears that refer with middle-ear transient condition. ${ }^{14,32,33)}$

\section{Tympanic perforations}

Conventional tympanometry detects tympanic perforations and pressure-equalization tube opening, but it yields no more middle ear information. WBT similarly detects perforations or open pressure- equalization tubes. In addition, WBT can be used to pre/post monitoring of pressure equalization tube. A perforation changes the absorbance pattern. In addition, the tympanographs and absorbance graphs yield middle ear data across the full frequency range. Perforated ears exhibit higher absorbances at low frequencies; interestingly, the smallest perforations have the largest effect. ${ }^{30)}$

\section{Ossicular chain disarticulation}

Eardrum thinning and ossicular chain disarticulation trigger high-level static compliance at $226 \mathrm{~Hz}$. However, it is not easy to distinguish these diseases by conventional tympanography. The existence of a resonance frequency identifies a disarticulation; the absorbance peak in the lower-frequency region is reduced. ${ }^{28,34)}$ Ossicular discontinuity shows a prominent notch in wideband reflectance around $400-800 \mathrm{~Hz}^{30,34)}$

\section{Semicircular canal dehiscence (SCD)}

Nakajima, et al. ${ }^{34)}$ reported that absorbance could be used to identify semicircular canal dehiscence (SCD) with 92\% sensitivity and $72 \%$ specificity. SCD shows SCD notch. It is a notch around $1 \mathrm{kHz}$ and smaller and not as sharp as the notch due to ossicular discontinuity. ${ }^{34)}$

\section{Postoperative monitoring}

It is not easy to evaluate a fragile middle ear after ear surgery; it is important to not apply pressure to the eardrum. WBT yields an absorbance graph in the absence of applied pressure. Middle ear status may thus be assessed immediately after surgery. $^{30,34)}$

\section{Others}

Pitaro, et al. ${ }^{35)}$ investigated wideband reflectance in newborns; significant increases were evident when $70-80 \%$ of the ear canal diameter was occluded.

Significant differences in energy reflectance curves were evident in Down's syndrome patients with middle ear pathologies. $^{36)}$

Pucci, et al. ${ }^{37)}$ used WBT to analyze acoustic absorbance in neonates exposed to passive smoking during pregnancy. The absorbances at low frequencies were lower than those at high frequencies at both ambient and peak pressures, but no difference between the exposure and non-exposure groups was evident.

Voss, et al. ${ }^{38)}$ reported that WBT can be used to monitor intracranial pressure change.

\section{Conclusion}

WBT yields valuable tympanographic and absorbance information about the middle ear. WBT is clinically valuable when evaluating middle ear effusions in infants, otosclerosis, disarticulations, and tympanic perforations; it can also be used for postoperative monitoring. More normative and pathologi- 
cal data on Koreans are required. WBT will also be useful to explore other middle ear diseases. In research laboratories, WBT can be used to detect hidden middle ear pathologies. WBT will become increasingly popular in the clinic and laboratory.

\section{REFERENCES}

1) Terkildsen K, Nielsen SS. An electroacoustic impedance measuring bridge for clinical use. Arch Otolaryngol 1960;72:339-46.

2) Van Camp KJ, Margolis RH, Wilson RH, Creten WL, Shanks JE. Principles of tympanometry. ASHA Monogr 1986;(24):1-88.

3) Nozza RJ, Bluestone CD, Kardatzke D, Bachman R. Identification of middle ear effusion by aural acoustic admittance and otoscopy. Ear Hear 1994;15(4):310-23.

4) Liu Z, Liu L, Yang K. [Comparison between $226 \mathrm{~Hz}$ probe tone tympanometry and spiral CT test in infants]. Lin Chung Er Bi Yan Hou Tou Jing Wai Ke Za Zhi 2012;26(19):887-9.

5) Baldwin M. Choice of probe tone and classification of trace patterns in tympanometry undertaken in early infancy. Int J Audiol 2006; 45(7):417-27.

6) Park M, Han KH, Jung H, Kim MH, Chang HK, Kim SH, et al. Usefulness of $1000-\mathrm{Hz}$ probe tone in tympanometry according to age in Korean infants. Int J Pediatr Otorhinolaryngol 2015;79(1):42-6.

7) Jerger J, Anthony L, Jerger S, Mauldin L. Studies in impedance audiometry. 3. Middle ear disorders. Arch Otolaryngol 1974;99(3): $165-71$.

8) Shahnaz N, Polka L. Standard and multifrequency tympanometry in normal and otosclerotic ears. Ear Hear 1997;18(4):326-41.

9) Funasaka S, Kumakawa K. Tympanometry using a sweep-frequency probe tone and its clinical evaluation. Audiology 1988;27(2):99-108.

10) Keefe DH, Bulen JC, Arehart KH, Burns EM. Ear-canal impedance and reflection coefficient in human infants and adults. J Acoust Soc Am 1993;94(5):2617-38.

11) Voss SE, Allen JB. Measurement of acoustic impedance and reflectance in the human ear canal. J Acoust Soc Am 1994;95(1):372-84.

12) Shahnaz N, Miranda T, Polka L. Multifrequency tympanometry in neonatal intensive care unit and well babies. J Am Acad Audiol 2008; 19(5):392-418.

13) Terzi S, Özgür A, Erdivanli ÖÇ, Coşkun ZÖ, Ogurlu M, Demirci M, et al. Diagnostic value of the wideband acoustic absorbance test in middle-ear effusion. J Laryngol Otol 2015;129(11):1078-84.

14) Aithal S, Kei J, Driscoll C, Khan A, Swanston A. Wideband absorbance outcomes in newborns: a comparison with high-frequency tympanometry, automated brainstem response, and transient evoked and distortion product otoacoustic emissions. Ear Hear 2015; 36(5):e237-50.

15) Feeney MP, Hunter LL, Kei J, Lilly DJ, Margolis RH, Nakajima HH, et al. Consensus statement: Eriksholm workshop on wideband absorbance measures of the middle ear. Ear Hear 2013;34 Suppl 1: 78S-9S.

16) Mazlan R, Kei J, Ya CL, Yusof WN, Saim L, Zhao F. Age and gender effects on wideband absorbance in adults with normal outer and middle ear function. J Speech Lang Hear Res 2015;58(4):1377-86.

17) Shahnaz N, Feeney MP, Schairer KS. Wideband acoustic immittance normative data: ethnicity, gender, aging, and instrumentation. Ear Hear 2013;34 Suppl 1:27S-35S.

18) Aithal S, Kei J, Driscoll C. Wideband absorbance in Australian Aboriginal and Caucasian neonates. J Am Acad Audiol 2014;25(5): 482-94.
19) Voss SE, Stenfelt S, Neely ST, Rosowski JJ. Factors that introduce intrasubject variability into ear-canal absorbance measurements. Ear Hear 2013;34 Suppl 1:60S-4S.

20) Aithal S, Kei J, Driscoll C. Wideband absorbance in young infants (0-6 months): a cross-sectional study. J Am Acad Audiol 2014;25(5):47181.

21) Özgür A, Müjdeci B, Terzi S, Özergin Coşkun Z, Yiğit E, Dursun E. Wideband tympanometry normative data for different age groups in Turkish population. J Int Adv Otol 2016;12(1):82-6.

22) Aithal S, Kei J, Aithal V, Manuel A, Myers J, Driscoll C, et al. Normative study of wideband acoustic immittance measures in newborn infants. J Speech Lang Hear Res 2017;60(5):1417-26.

23) Polat $Z$, Baş B, Hayır D, Bulut E, Ataş A. Wideband tympanometry normative data for Turkish young adult population. J Int Adv Otol 2015;11(2):157-62.

24) Feeney MP, Stover B, Keefe DH, Garinis AC, Day JE, Seixas N. Sources of variability in wideband energy reflectance measurements in adults. J Am Acad Audiol 2014;25(5):449-61.

25) Sun XM. Wideband acoustic immittance: normative study and testretest reliability of tympanometric measurements in adults. J Speech Lang Hear Res 2016;59(4):819-34.

26) Keefe DH, Hunter LL, Feeney MP, Fitzpatrick DF. Procedures for ambient-pressure and tympanometric tests of aural acoustic reflectance and admittance in human infants and adults. J Acoust Soc Am 2015; 138(6):3625-53.

27) Ryu G, Cho YS. Wideband absorbance measurements: norms and middle ear disorders. Korean J Otorhinolaryngol-Head Neck Surg 2017;60(2):55-62.

28) Shahnaz N, Bork K, Polka L, Longridge N, Bell D, Westerberg BD. Energy reflectance and tympanometry in normal and otosclerotic ears. Ear Hear 2009;30(2):219-33.

29) Beers AN, Shahnaz N, Westerberg BD, Kozak FK. Wideband reflectance in normal Caucasian and Chinese school-aged children and in children with otitis media with effusion. Ear Hear 2010;31(2): 221-33.

30) Feeney MP, Grant IL, Marryott LP. Wideband energy reflectance measurements in adults with middle-ear disorders. J Speech Lang Hear Res 2003;46(4):901-11.

31) Guan X, Seale TW, Gan RZ. Factors affecting sound energy absorbance in acute otitis media model of chinchilla. Hear Res 2017;350:22-31.

32) Keefe DH, Fitzpatrick D, Liu YW, Sanford CA, Gorga MP. Wideband acoustic-reflex test in a test battery to predict middle-ear dysfunction. Hear Res 2010;263(1-2):52-65.

33) Voss SE, Herrmann BS, Horton NJ, Amadei EA, Kujawa SG. Reflectance measures from infant ears with normal hearing and transient conductive hearing loss. Ear Hear 2016;37(5):560-71.

34) Nakajima HH, Rosowski JJ, Shahnaz N, Voss SE. Assessment of ear disorders using power reflectance. Ear Hear 2013;34 Suppl 1:48S-53S.

35) Pitaro J, Al Masaoudi L, Motallebzadeh H, Funnell WR, Daniel SJ. Wideband reflectance measurements in newborns: relationship to otoscopic findings. Int J Pediatr Otorhinolaryngol 2016;86:156-60.

36) Soares JC, Urosas JG, Calarga KS, Pichelli TS, Limongi SC, Shahnaz $\mathrm{N}$, et al. Wideband reflectance in Down syndrome. Int J Pediatr Otorhinolaryngol 2016;87:164-71.

37) Pucci BPC, Roque NMCF, Gamero MS, Durante AS. Acoustic absorbance measurements in neonates exposed to smoking during pregnancy. Int J Pediatr Otorhinolaryngol 2017;95:51-6.

38) Voss SE, Adegoke MF, Horton NJ, Sheth KN, Rosand J, Shera CA. Posture systematically alters ear-canal reflectance and DPOAE properties. Hear Res 2010;263(1-2):43-51. 


\section{정답 및 해설}

답 (4)

해 설 미로누공은 대부분 진주종 병변에 의하여 생기는데 외반고리관 누공이 가장 흔하다. 누공검사의 55 70\%에서 양성을 보이며, 누공이 있는 쪽에 양압을 가하였을 때 시행하는 쪽으로 안진이 유발된다. 누공이 의심되면 다른 부위의 수술을 모두 해결한 후에 마지막 단계에서 누공부위를 처리해야 한다. 누공의 크기가 작고 우측 귀의 청력이 정상이므로 2차 수 술로 제거하기보다는 진주종 기질을 제거한 후에 연골막 또는 근막, bone paste 등으로 즉시 덮어준다. 참고문헌: 대한이비인후과학회. 이비인후과학 두경부외과학 교과서. 서울: 일조각;2009. p.632. 